\title{
The Parasitic Communities of the Rock Pigeon Columba livia from Iraq: Component and Importance
}

\author{
Irak’ta Kaya Güvercini (Columba livia) Parazitleri: Türler ve Önemi
}

\author{
Shlemon Al-Barwari', Isam Saeed ${ }^{2}$ \\ 'Division of Biology, Former University of Salahaddin, Erbil, Iraq \\ 2Department of Bioanalytiker, University Collage of Sjælland, Næstved, Denmark
}

\section{ABSTRACT}

Objective: The main objectives of the present study were to investigate the rock pigeon parasitic communities from Iraq as well as reporting on the prevalence and intensity of various infections from both sexes.

Methods: An examination of 128 specimens of the live rock pigeon Columba livia from Iraq was undertaken. The samples were obtained from several localities of Iraq. Blood samples were examined for haemoprotozoa, carcasses were investigated for the ectoparasites throughout their body skins and feathers, and the alimentary canal was examined for protozoans and helminths.

Results: Twenty-seven species of parasites were identified. They comprised 1 Fungi, Candida sp.; 4 Protozoa, Eimeria labbeana, Trichomonas gallinae, Haemoproteus columbae and Plasmodium sp.; 8 Cestoda, 4 of each of the genera Cotugnia and Raillietina; 4 Nematoda, Ascaridia columbae, A. galli, Capillaria obsignata and Synhimantus spiralis; and 10 Arthropoda, the commonest of which were the wing and tail feather louse Columbicola sp. and the pigeon louse fly Pseudolinchia canariensis. Infection indices are provided for each species and in respect to both sexes of the host.

Conclusion: The issue of zoonosis is raised, so is the role of the rock pigeons in acting as a reservoir and spreading some of the disease agents associated with other avian populations including poultry. Seven of the species are newly introduced to the parasitological list of Iraq and for this country the rock pigeon is a new host record for another 9 of the endoparasites that were diagnosed.

(Turkiye Parazitol Derg 2012; 36: 232-9)

Key Words: Rock pigeon, parasitic communities, endoparasite, ectoparasite, Iraq

Received: 12.04 .2012

Accepted: 02.08.2012

\section{ÖZET}

Amaç: Bu çalışmanın temel amacı, Irakta'ki kaya güvercini topluluklarında parazit türleri, enfeksiyon sıklığı, şiddeti ve cinsiyete bağlı dağılımını araştırmaktır.

Yöntemler: Irak'ın farklı yerlerinden 128 canlı kaya güvercini (Columba livia) temin edildi. Kan örnekleri haemoprotozoa yönünden, deri ve tüyler ektoparazit yönünden ve sindirim kanalı ise protozoa ve helmint yönünden muayene edildi.

Bulgular: Yirmi yedi tür parazit tespit edilmiştir. Bunlar 1 mantar; Candida sp., 4 protozoa türü; Eimeria labbeana, Trichomonas gallinae, Haemoproteus columbae ve Plasmodium sp., 8 sestod türü; 4 Cotugnia ve 4 Raillietina türü; 4 nematod; Ascaridia columbae, A. galli, Capillaria obsignata ve Synhimantus spiralis ve 10 arthropod türü (en yaygın türler Columbicola sp. ve Pseudolinchia canariensis) olarak belirlenmiştir. Enfeksiyon yaygınlığı, şiddeti her tür için ve her iki cinsiyet açısından irdelenmiştir.

Sonuç: Irak parazit faunasına eklenen yedi tür tanımlanmış ve Irak kaya güvercinlerinde ilk kez rastlanan 9 endoparazit hakkında bilgi verilmiştir. (Turkiye Parazitol Derg 2012; 36: 232-9)

Anahtar Sözcükler: Kaya güvercini, parazit, endoparazit, ektoparazit, Irak

Kabul Tarihi: 02.08.2012

Address for Correspondence / Yazışma Adresi: Dr. Isam Saeed, Department of Bioanalytiker, University Collage of Sjælland, Næstved, Denmark Phone: +45 28936531 E-mail: parasitology@live.dk doi:10.5152/tpd.2012.56 


\section{INTRODUCTION}

The rock pigeon, Columba livia, is essentially a free-living and cliff-dwelling granivorous species, but which is also a direct predecessor of the domestic subspecies C. I. domestica. It is readily recognisable that these two populations have kept many properties in common and actually even retained a certain degree of synanthropy. This suggests that their relation is much closer than some links of consanguinity.

Pigeons are amongst the most prevalent and readily observable birds in all provinces of Iraq. Besides constituting a small part of human food, they are used for ornamental or appearance purposes (fancy pigeons) as well as pets, human sport (racers and performers), for biological and medical experimentations, and for teaching the art of taxidermy. Pigeons in this part of the world also have a rich historical and anecdotal background.

Due to the fact that flocks of rock pigeons have adapted so well to life in association with human habitation, they become pests in domestic, commercial and public premises. More importantly, pigeons pose a serious health threat to millions of people and some of their economic animals. In Iraq, Al-Jumaily et al. (1) presented evidence that the population of the rock pigeon carry such dangerous disease agents as the bacterium Salmonella typhimurium and Newcastle virus. Besides, according to Soulsby (2), Ritchie et al. (3), Kaufmann (4), and Barnek et al. (5), wherever found across the globe, pigeons might be potential carriers of numerous other harmful pathogens and therefore a habitual tool to contaminate food and water and circulate illnesses such as psittacosis (ornithosis), histoplasmosis, aspergillosis, cryptococcosis, toxoplasmosis, tuberculosis, vibriosis, encephalitis, $\mathrm{Q}$ fever, pox, staphylococcosis, and listeriosis. Furthermore, pigeons themselves are subject to contracting not only the Newcastle virus but many other serious diseases, produced by other viruses, rickettsiae, bacteria, fungi, protozoa, helminths and arthropods (6-10). The reassessment of the bulk of the data produced some invaluable information that these birds would might appear to be of relevance to both wild and domestic avifauna as well as to host-parasite relationships, antigenic cross connections, zoonoses, sanitary surveillances, and control measures.

Judging from the available data directly relevant to the parasitism in the Iraqi populations of rock and domestic pigeons, the information regarding the identity, prevalence, intensity and endoparasite-ectoparasite assemblage of the parasitic forms likely to be associated with these birds is still far from adequate (11-24). Therefore, the main objectives of the present study were to investigate the above themes in a relatively larger sample of the rock pigeon in the hope of providing new data and clarifying some other pertinent issues.

\section{METHODS}

A sample of 128 specimens of the eastern rock pigeon Columba livia (Gmelin, 1789), subspecies gaddi Zarudny and Loudon, 1906, was randomly selected and used in this study. It comprised 58 males and 70 females, all of which were at the adult stage, albeit of different ages. These pigeons were captured alive between February 1990 and July 1991 from different localities within the country.
A general examination of each pigeon was performed and the majority of them were found to be lively and seemingly healthy looking. The average figures of some physical parameters of the specimens were: body weight $221.3 \mathrm{gm}$, wing cord $20.7 \mathrm{~cm}$, tail length $10.3 \mathrm{~cm}$, tarsus length $3.3 \mathrm{~cm}$ and bill length $1.88 \mathrm{~cm}$.

A small amount of blood was obtained from the brachial vein of each bird and used for the preparation of thin smears. These were air-dried, fixed in absolute methanol and stained with $5 \%$ Giemsa solution ( $\mathrm{pH}$ 7.2) before examining them using an oil immersion lens for the presence of haemoprotozoans. Haemoproteus and Plasmodium parasites were differentiated following their respective descriptions and illustrations in the literature, for example, presence in the host's peripheral red blood corpuscles (RBCs) of gametocytes for the former and schizonts for the latter $(3,5,25)$. In both cases, a considerable number of the infected cells were not of normocytic size range but rather revealed some enlargement and structural distortion, as may also happen to the seriously damaged and dying cells of other tissues as a result of radiation and various other types of cyto-injurious agents (26). The parasitisation levels for either of these blood organisms were estimated on the basis of randomly examining 1,000 RBCs from each bird and then determining the percentage of infected cells. The data were averaged and so presented.

Within an hour after a pigeon was euthanised, any ectoparasites were collected from the skin and/or plumage. Lots obtained from different host specimens were separately kept to avoid any confusion. In many cases, it was possible to identify these species depending on their distinctive characteristics, and hence also determine their prevalence and intensities, by directly examining them under low-power objectives $(2,12,27)$. Otherwise, they were preserved in $70 \%$ isopropyl alcohol (lice and mites) or $70 \%$ ethanol (other species) to be prepared and definitely identified later. To facilitate this process, the ectoparasites were subjected to an overnight clearance in 10\% potassium hydroxide, washed, stained in $0.7 \%$ solution of Congo red, washed to remove excess stain, dehydrated in alcohol, cleared in xylene and permanently mounted in Canada balsam.

The cadaver of each pigeon was eviscerated. This process involved complete separation of the digestive tract from other organs by laparotomy. The tract, from gullet to rectum, including the gizzard and paired caeca, was then cut open. The content and scrapings from the mucosa of each anatomical part waere examined. When present, helminths from each bird were collected, cleaned in saline, their numbers counted, initially identified with the help of a dissecting microscope, and then preserved in $70 \%$ ethanol for subsequent processing. Attempts to identify the species of unicellular organisms (fungi and protozoans) were also made from fresh samples in the form of impermanent preparations examined with high-power objectives.

Permanent preparations of the gastrointestinal parasites were frequently made. This was done following the standard procedures for unicellular organisms, cestodes and nematodes. Relevant descriptions, found in Levine (28), Schmidt (29), Kaufmann (4), and Barnek et al. (5), aid the process of analysing the diagnostic features of the parasites and ultimately in achiev- 
ing species-rank identification for most of them. Furthermore, definite identification of some of the species was decided by the experts' opinions previously received from the British Museum (Natural History) and CAB International.

Infection by the flagellate protozoan Trichomonas gallinae was infrequently predicted by the presence of pale cream-coloured lesions inside the host's mouth. However, it was always confirmed by actually finding the motile trophozoites of this organism in the microscopic preparations of fresh scrapings taken from the oral mucosa. The identification of other gastrointestinal unicellular parasites (fungi and coccidians), and sometimes helminths' ova, was achieved by microscopic examination of fresh faecal samples prepared, as needed either by the sedimentation or zinc sulfate floatation techniques. The level of parasitisation, in terms of parasite burdenfor the unicellular organisms other than for haemoprotozoans, was arbitrarily determined by designating 1+ for very mild asymptomatic form of infection and where only a small population of the parasite was detectable, and $2+$ for moderate degree of infection and symptoms such as slight diarrhoea. No case of massive infection and acute symptoms, including emaciation, listless, dull and ruffled plumage and severe diarrhoea, was observed for any of the sampled pigeons.

Thus, whenever possible, both of the principal parasitisation indices, namely, "infection rate" and "parasite burden", were determined. The first index represents the prevalence of a parasite species among the examined specimens of its host, whereas the second is the average load of the parasite number actually present and hence may be taken as an indicator for the intensity of infection.

\section{RESULTS}

Twenty-seven forms of parasites were identified in and on the rock pigeon specimens examined in this study (Table 1). The global infection prevalence was 100\%; that is, every bird was positive for at least one parasite. In fact, it was a parasitic association, which was distinguished as a common feature, since the majority of pigeons harboured 6-9 species concurrently, a few of them hosted up to 12 , and one specimen even had 15 species. These parasites belong to 5 main taxonomic categories, namely, Fungi, Protozoa, Cestodes, Nematodes and Arthropodes .

With regard to the unicellular organisms, a specific identification of Eimeria labbeana, Trichomonas gallinae and Haemoproteus columbae was accomplished. However, such definite identification was not possible for the yeast-like fungi of the genus Candida and apicomplexan protozoan of the genus Plasmodium. Therefore, these latter 2 forms were retained at the generic rank.

In respect to the gastrointestinal unicellular organisms, the dominant species was T. gallinae. As to haemoprotozoans, the infection rate of $H$. columbae was higher than for Plasmodium sp. Only in $H$. columbae was the infection rate significantly higher in males than females. In no case was a pigeon solely infected with one of these unicellular parasites and almost always the presence of Plasmodium was associated with that of Haemoproteus.
Eight species of cyclophyllidean cestodes were found. They are Cotugnia polyacantha, C. satpuliensis, C. columbae, C. digonopora, Raillietina (=Skrjabinia) tetragona, R. carpohagi, R. bonini (=Hymenolepis columbae) and R. fuhrmanni. All these tapeworms belong to the family Davaineidae. They were mostly recovered from the ileal part of the small intestine. The vast majority of their specimens were attached to the mucosa through their scolices and probably enforced their anchoring by a cushion-shaped rostellar apparatus. The differential diagnosis of some of them was only possible upon close examination of their scolices and comparison with the published descriptions and illustrations. In other words, when scolices were missing, examination and morphometrics of the strobilae, proglottids and ova of these tapeworms were not always sufficient for a definite identification.

Among these tapeworms, the representative degree of $R$. fuhrmanni and $R$. bonini seemed to be less than those of the rest. Variations in the individual relationships between sexes of pigeons and indices of their parasitisation with the tapeworm species appeared to be significant in the majority of cases. Nonetheless, figures for such variations seem less suggestive of a genuine difference due to certain intrinsic factors, whether in terms of prevalence or intensity, upon averaging the data for the 2 tapeworm genera or for all their species involved in that matter.

Four species of nematode parasites were found in this study. They comprise the 2 allied large roundworms Ascaridia columbae and A. galli the hairworm Capillaria obsignata, C. columbae and the spiralworm Synhimantus (=Dispharynx) spiralis. All these parasites inhabit the small intestine and the incidence data indicate that they were dominated by the pigeon ascarid species. Then, with the exception of the fowl ascarid, male pigeons were found to be more prone to infection by these nematodes than their female counterparts, whereas the reverse was the case in respect to the index of parasite burden.

As shown in Table 1, as many as 10 species of ectoparasites were collected and differentiated from the pigeons that were sampled. Eight of them were insects, 6 belonging to Mallophaga, namely, the wing and tail feather chewing lice Columbicola sp., the down feather or fluff louse Goniocotes gallinae, and the small pigeon louse Campanulotes bidentatus; the small body louse Menacanthus cornutus, the head and neck louse Cuclotogaster heterographus and the pigeon whole body louse Hohorstiella lata; 1 belongs to Diptera, namely, the pigeon flatfly or louse fly Pseudolynchia canariensis, and 1 belongs to Siphenoptera, namely, the cat flea Ctenocephalides felis. The other 2 ectoparasites found belong to Arachnida, comprising 1 Acarina, namely, the fowl red mite Dermanyssus gallinae and 1 Parasitiformes, namely, the Persian poultry soft tick Argas (Persicargas) persicus.

The infestation rates of the above external parasites were variable, but only the Columbicola sp. and $P$. canariensis were noted infesting more than half of the sampled pigeons. The level of infestation in terms of parasite burden also showed variation and in such a pattern that Columbicola sp was the highest level and $D$. gallinae the lowest. Differences in the infestation of the 2 sexes were often manifested. However, the average data for all 
species involved tends to diminish them, where $\mathrm{p}$-values fall under the threshold for significance level.

\section{DISCUSSION}

A randomised sample of the rock pigeons probably provided a helpful set of morphometric measurements, employed before in connection with the infection prospective study by Dranzoa et al. (8). Such data should be provided in time to serve as an arbitrary indicator of the development and maintenance of body condition and viability fitness by the adults, as well as to hygiene practice. Data from different countries and various health conditions for these birds are needed to substantiate the impact of such a relationship. On the other hand, the parasitological findings seem to validate a fairly good health status of the pigeons. Such a situation may be explained by a number of interrelated factors. For example, suitable climatic conditions from the parasite aspect, and from the host aspect poor sanitation, crowding, low-energy food, interspecific and intraspecific competitions for resources.

Candida sp. was encountered in about a quarter of the pigeons. - However this was always in a non-invasive form and without a single case of massive infection and associated clinical signs, which often cause the appearance of whitish plaque in the upper digestive tract. The prediction of Tsai et al. (30), Ritchie et al. (3), and Kaufmann (4) is that this worldwide parasite may occur naturally in the alimentary canal of pigeons and doves as well as a wide range of other avian species, including the commercially important ones like chickens, turkeys, ducks, geese, pheasants, partridges and quails.

The oocysts of Eimeria are also commonly transmitted to and found in otherwise intact pigeons without gross pathological manifestations of acute gastroenteritis (31). Indeed, low infection by these parasites may even be protective by boosting the

Table 1. The parasite component community of the eastern rock pigeon (Columba livia gaddi) from Iraq together with infection sites and indices

\begin{tabular}{|c|c|c|c|c|c|}
\hline \multirow[t]{2}{*}{ Parasite name } & \multirow[t]{2}{*}{ Infection site } & \multicolumn{2}{|c|}{ Infection rate $(\%)$} & \multicolumn{2}{|c|}{ Parasite burden } \\
\hline & & $\hat{\sigma}$ & 우 & $\hat{\sigma}$ & 우 \\
\hline Candida sp. & Upper digestive tract & 22.0 & 28.3 & $1+$ & $1+$ \\
\hline E. labbeana & Intestine (oocysts in faeces) & 17.1 & 24.5 & $1+$ & $1-2+$ \\
\hline T. gallinae & Upper digestive tract & 58.5 & 71.7 & $2+$ & $2+$ \\
\hline H. columbae & Gametocytes in RBCs & 73.2 & 49.1 & 1.5 & 0.9 \\
\hline Plasmodium sp. & Schizonts in RBCs & 31.7 & 41.5 & 1.1 & 1.6 \\
\hline C. polyacantha & Small intestine & 19.5 & 18.9 & 4.5 & 5.0 \\
\hline C. satpuliensis & $==$ & 17.6 & 11.8 & 5.3 & 4.7 \\
\hline C. columbae & $==$ & 11.8 & 8.8 & 2.0 & 3.3 \\
\hline C. digonopora & $==$ & 7.3 & 5.7 & 1.7 & 1.3 \\
\hline R. tetragona & $==$ & 9.8 & 20.8 & 2.5 & 1.8 \\
\hline R. (R.) carpohagi & $==$ & 8.8 & 2.9 & 4.3 & 3.0 \\
\hline R. bonini & $==$ & 4.9 & 1.9 & 2.5 & 2.0 \\
\hline R. fuhrmanni & $==$ & - & 3.8 & - & 1.5 \\
\hline A. columbae & $==$ & 24.4 & 13.2 & 2.6 & 4.0 \\
\hline A. galli & $==$ & 5.9 & 11.8 & 2.0 & 3.3 \\
\hline C. obsignata & $==$ & 9.8 & 3.8 & 2.8 & 2.3 \\
\hline S. spiralis & $==$ & 4.9 & 1.9 & 3.5 & 3.0 \\
\hline Columbicola sp. & Wing and tail feather & 64.4 & 57.6 & $\sim 60$ & $\sim 45$ \\
\hline G. gallinae & Down feather & 17.1 & 15.1 & $\sim 30$ & $\sim 25$ \\
\hline C. bidentatus & Body skin & 7.3 & 1.9 & $\sim 30$ & $\sim 15$ \\
\hline M. cornutus & $==$ & 12.2 & 13.2 & $\sim 30$ & $\sim 30$ \\
\hline C. heterographus & Head and neck & 4.9 & 17.0 & $\sim 35$ & $\sim 25$ \\
\hline H. lata & $==$ & 7.3 & 11.3 & $\sim 20$ & $\sim 40$ \\
\hline P. canariensis & $==$ & 61.0 & 43.4 & 3.4 & 5.7 \\
\hline C. felis & $==$ & 4.9 & 9.4 & 2.0 & 2.7 \\
\hline D. gallinae & $==$ & 7.3 & 18.9 & 3.0 & 2.8 \\
\hline A. persicus & $==$ & 14.6 & 17.0 & 4.2 & 11.5 \\
\hline
\end{tabular}


immune responses against further infections, as is the case with poultry $(4,5)$. However, when large numbers of mature and sporulated oocysts are ingested, especially by the susceptible and debilitated birds, inevitably profound immunosuppression will have the upper hand which leads to the development of a true coccidiosis $(2,3)$. E. labbeana was first recorded from Iraq in domestic pigeons by Al-Janabi et al. (15) and in rock pigeons by Shamsuddin et al. (22). In comparison with the present infection rate of $21.3 \%$, the data from other countries cover a full range. Dranzoa et al. (8) detected no oocysts among the intestinal material of the rock pigeons from Uganda; whereas Kulisic (32) from Yugoslavia, Martinez-Moreno et al. (33) from Spain, Boado et al. (6) from Cuba, Catelli et al. (7) from Italy and Koroglu et al. (31) from Turkey obtained infection rates in specimens of the same host of $24.2 \%, 63.3 \%, 68.8 \%, 25.0 \%$ and $15.1 \%$, respectively. The two remarkably similar species of coccidians more often found by these workers, whether or not confirming their identification through cultural sporulation, were E. labbeana and E. columbarum.

The infection rate of T. gallinae was the highest among all the parasites isolated in this study. This is a finding that one would expect, for example, since this flagellate protozoan is of cosmopolitan distribution and generally looked upon as a normal digestive tract inhabitant. Then, as also mentioned by Levine (28) and Soulsby (2), the vast majority of the older pigeons may be carriers of this organism. This means that they easily can introduce it to their young squads while feeding them the regurgitated holocrine substance or "cropmilk". The levels of parasite burden in male and female pigeons, as noted in this study, would prove that the presence of light infections by $T$. gallinae is by no means indicative of a true and cankerous trichomoniasis. MartinezMoreno et al. (33) and Toulah (34) identified trichomonads in the upper digestive tract and associated organs of the normal wild and domestic pigeons from Spain and Saudi Arabia, respectively. The respective incidence rates they presented were $79.2 \%$ and $63.0 \%$, which are comparable to those of the present study. Noticeably lower figures for T. gallinae infections in rock pigeons were presented by other, for example, 11.0\% from Chile (9), $26.5 \%$ from Brazil (35) and $32.0 \%$ from Italy (7). I It would be possible to say that a considerable proportion of the world's populations of the rock pigeon at present harbour this protozoan.

The haemoprotozoan $H$. columbae has been recorded previously from Iraq, in both rock pigeons and domestic pigeons (15, $22,24)$. The latter researcher obtained an approximateinfection incidence and intensity of $39 \%$ and $23 \%$ in RBCs respectively; the first figure is somewhat lower and the second one significantly higher in comparison with the present data. This is the first mention of a Plasmodium sp. occurrence in the rock pigeons from Iraq. Parasitaemia due to these parasites has been repeatedly detected in pigeons and many other species of wild and domestic birds worldwide, for example, for the haemoproteid species, Martinez-Mareno et al. (33) from Spain, Earle and Little (36) from South Africa, and Dranzoa et al. (8) from Uganda found in the rock pigeon samples infection rates of $26.7 \%, 73.0 \%$ and $76.5 \%$, respectively. Gulanber et al. (37) and Senlik et al. (38) obtained average infection rates for $H$. columbae in adult domestic pigeons from Turkey of 43.2 and $18.8 \%$, respectively.
In contrast to the findings of Earle and Little (36), male pigeons in this study were found more prone than females to infection by $H$. columbae. On the other hand, Senlik et al. (38) were unable to detect a significant difference in the infection rate of this parasite in terms of host sexuality, but they found that such an infection was a subject of marked seasonal variation. Several endogenous and exogenous factors may have an accumulative influence on the parasitisation of both sexes of the pigeons by these parasites, such as host's hormones and humoral compounds, age and nutritional state, behaviour and habits, as well as the season of the year and ecological and physical features of the regions.

Concurrent with the infection by $H$. columbae, Dranzoa et al. (8) provided a figure of $29.4 \%$ for infection of the rock pigeons by the Plasmodium parasites. This figure is close to that obtained for male but lower than that for female pigeons in the present study. The general opinion is that this and the preceding blood parasite are related in many characters and considered by many to be either benign or of mild effect $(36,39)$. They are continually circulated around the world and any variations in their prevalence, intensity and health impact, whether sex-related, seasonal-related or spatial-related, might depend on the susceptibility of the host species involved, their ages, habitats, as well as congruence, transmission, density and feeding habits of their vectors. As also referred to by the forenamed workers, the respective incriminated vectors of these parasites have been identified. They include a number of mosquitoes of the genera Culex and Aedes for Plasmodium and flies of the genera Hippoboscid and Phlebotomus and midges of the genus Culicoides for Haemoproteus spp., respectively. Many species of these haematophagous biting insects are present throughout Iraq and its neighbours.

With regard to the tapeworms, the present findings suggest the existence of many interspecific similarities for the members of both of the genera Cotugnia and Raillietina. This is in agreement with Schmidt (29), Sawada et al. (21) and Dranzoa et al. (8), the information gathered from the study of ova and gravid proglottids from the host's excrement may be useful but often not sufficient for their definite diagnosis. The identification of a species level among these cestodes is best made by detecting the parasites' strobilae and scolices among the scrapings of the intestinal mucosa and carefully analysing the characteristics revealed by the microscopic inspection.

For R. bonini, this is the first mention in Iraq. However, it has been reported in samples of the rock pigeons from several other counties; frequently but not always with comparably low rates, for example, $0.9 \%$ from Italy (7), 1.0\% from Spain (33), 7.5\% from Yugoslavia (32), and 45.7\% from Brazil (40). The fowl tapeworm C. digonopora was previously reported from Iraq only in the wood pigeon (41). It is known to infect chickens and other poultry in many parts of the world. With respect to the rock pigeon, Chahota et al. (42) found the infection rate of this species in a sample from India to be $6.25 \%$. The other species of tapeworms encountered were all recorded previously in pigeons, doves or chickens from Iraq, viz., C. polyacantha in 18.0\% of rock pigeons from the Baghdad area (14); C. satpuliensis in $29.4 \%$ of domestic 
pigeons from Arbil (21); C. columbae in $0.22 \%$ of domestic pigeons from northern Iraq (24); $R$. tetragona in $18.5 \%$ of domestic fowls from the Mosul district (43), and in $0.22 \%$ of domestic pigeons from northern Iraq (24); R. carpohagi in $15.4 \%$ of domestic pigeons from Arbil (21); and R. fuhrmanni in $17.0 \%$ of palm doves from the Baghdad area (14). It is worth mentioning that, among the new davaineids described from the rock pigeons of Saudi Arabia by Magzoub et al. (44), there was a species having morphometrics close to those of $R$. tetragona and another one to $C$. digonopora.

In conformity with the situation in the chukar partridge, when the global data for the cestode infection of male and female pigeons were considered, no significant sex differences were apparent (45). Such observations seem to contradict those of Srivastava and Srivastava (46), where significantly higher annual mean figures for infection by these parasites were obtained in the female rock pigeons from Allahabad, India. These researchers attributed such differences to enhanced susceptibility in female birds produced by greater stress due to frequent fluctuation in their hormonal and metabolic activities during the active reproductive stages. On the other hand, the significant seasonal variations noted by Al-Aloosi (41) in the infection rates of some intestinal tapeworms in the wood pigeon (C. palumbus) from Iraq might be attributed to the changeable behaviour of this host species, particularly in relation to annual fluctuations in the foraging habitat.

No doubt availability of information relevant to the ecology and life histories of the avian tapeworms in Iraq will be very useful in order to investigate systematically their epidemiology and control. Elsewhere, these parasites were shown to have evolved indirect cycles whereby the ova develop into infective larvae (cysticercoids) in the tissues of some invertebrates $(4,5,29,47)$. The identity of these intermediaries may vary with the tapeworm species but it often comprises one or other of such insects as houseflies and allied dipterans, some hymenopterans such as ants, and some beetle species.

Only one of the species of the presently found nematodes in the rock pigeons was previously identified from Iraq which is $A$. galli in domestic fowls $(43,48)$ and domestic pigeons (24). The approximate figures for infection rate and parasite burden presented by the latter researcher were $56.4 \%$ and $30 \%$. Higher infection figures with nematode parasites were found by Senlik et al. (49) in the domestic pigeons from the Bursa province of Turkey. Similar to many other pigeon parasites, infection by nematodes that involve low incidences and/or low intensities are expected to be often endurable. Only those infections that become too severe are dangerously harmful, which are frequently found in disabled, weakened or senile hosts.

The individual and global infection indices obtained for the nematode species are in general agreement with the range of data obtained by other workers also for apparently healthylooking and free-living pigeons $(6,7,9,32,33,40)$. Nevertheless, such hosts must be treated as a potential source of infection to domestic pigeons and other susceptible birds. In this connection, each of the 4 nematode parasites that were identified in this study has a direct life cycle $(2-5,50)$. This means that the ova are passed in faeces and under favourable environmental factors (especially high temperature and adequate humidity) they develop into infective stage.

Ectoparasites are prevalent on wild and domestic pigeons throughout the world. Both their host specificity and deleterious impact vary greatly. In Iraq, the works of Khalaf $(18,19)$ and AbulHab $(12,13)$ reveal that all species of these parasites presently found were previously encountered on poultry and sometimes on pigeons and doves. However, these earlier studies were largely faunistic in nature. On the other hand, the infestation rates presented by Zangana (24) and Abdul-Karim et al. (10), for some of these parasites fit within the respective ranges of the present data. The infestation situation of pigeons is probably quite similar to that of chickens $(51,52)$; that is, that the patterns of relationship between ectoparasites and their surrounding environment are important in this respect. Specifically, it is likely that the atmospheric temperature constitutes the dominant factor in controlling their occurrence, abundance and diversity throughout the year.

As stated in results, the Columbicola lice collected in this study were reserved at the generic level. These interesting insects were first noticed in Iraq on pigeons and collared doves in Baghdad and identified as C. columbae and Columbicola sp., respectively (18). Pigeons from the Na'maniyah district about $120 \mathrm{~km}$ south of Baghdad were also found to be infested by C. columbae (19). This largely pigeon and dove specific louse was recently thought to be the same as that found in north Iraq on turkeys and chukar partridges $(45,53)$. However, earlier examination by Eichler and Abul$\mathrm{Hab}$ (17) of the Columbicola forms of feather lice occurring on domestic and rock pigeons at Baghdad concluded that they all belong to $C$. montschadskyi. Hitherto, only a third species of this group of closely allied lice was reported from the Iraqi pigeons, and that is $C$. tschulyschman $(11,12,24)$. The comparable forms of lice infesting pigeons in Turkey were invariably classified as $C$. columbae $(54,55)$. Furthermore, this species is of common occurrence on pigeons across Europe $(27,56,57)$.

The pigeon flatfly $P$. canariensis was previously observed on pigeons in the Mosul province of north Iraq (16). It was also found infesting Istanbul pigeons (54). This louse-like dipteran fly feeds on blood and develops especially in juvenile birds. It also contributes in spreading some obligate blood parasites including Haemoproteus spp. and Leucocytozoon spp. $(25,39)$. Furthermore, a number of lice and mites species are believed to have evolved a phoretic association with this particular species of hippoboscid fly (8). They normally do not feed on these flies but rather may use them for transport from one bird individual to another.

The poultry red mite $D$. gallinae is another blood-sucking parasite. According to Ritchie et al. (3) and Kaufmann (4), D. gallinae may even be fatal especially to young birds, as well as transmitting viral, rickettsial and protozoan diseases including equine encephalitis and borreliosis. Inhabitants of the pigeon-infested buildings in Iraq often complain of bites. Indeed, some coincident events involving the red mites on the pigeons sampled for the present study confirmed that this species is prone to attack and bite human beings. 
The Persian soft tick A. persicus is also a bloodsucker. It is prevalent among poultry in north Iraq, especially on traditionallyraised free-range chickens that have been denied adequate health care (Al-Barwari and Saeed - unpublished observation) (58). It is well documented that this tick is an important agent in spreading viruses, rickettsiae, bacteria and protozoa among pigeons and many other wild and domestic animals $(2,4,59)$.

\section{CONCLUSION}

A number of final conclusions can be drawn from the findings of this study and reflections upon their comparison with the data of other workers. They are:

1. The rock pigeons constitute a continuum subject of infection by a diversified community of endoparasites as well as infestation by ectoparasites.

2. Adult rock pigeons can tolerate certain thresholds of naturally occurring disease agents without displaying gross pathological changes and clinical signs of sickness. Therefore, these birds should better be looked upon as a potential reservoir for spreading many parasitic and microbial species to other types of pigeons and doves, poultry, game birds, prey birds and some members of other avian orders.

3. Hyper-parasitisation is generally rare in the population of free-living rock pigeons, but, when occurring, may result in developmental instability. This may be attributed to a disturbance in the natural equilibrium between the hosts and parasites leading to a disease outbreak accompanied by acute symptoms and increased mortality rate $(8,20)$.

4. To man, pigeons of today seem to have completely outlived all their past usefulness and instead classified as vermin. An increased number of them in the intimate human environment may constitute sanitary, nuisance and other troubles.

5. Any comprehensive strategy aiming at the effective control of pigeon parasites, should adopt the policy of simultaneously controlling a number of invertebrate species, which serve either as vectors or intermediaries for many forms of these parasites.

6. The quality of eradication of pigeons from around the poultry breeding and layer farms as well as from food and water handling facilities is an essential factor forcounteracting disease dissemination. The same of course applies to other bird pests like house sparrows and starlings.

\section{Acknowledgments}

The researchers wish to thank the Medical and Educational Colleges of Salahaddin University, Erbil, Iraq, for encouragement and support during the period this study was carried out. They are also indebted to Drs. D. I. Gibson (British Museum of Natural History), L. F. Khalil (CAB International, Oxon), J. Abul-Hab (Institute of Endemic Diseases, Baghdad), and I. Kaddou (College of Science, Baghdad University) for their help or discussions especially relevant to the identification of some parasites. Photocopies of some of the references cited were kindly provided by the British Library.

\section{Conflict of Interest}

No conflict of interest was declared by the authors.

\section{REFERENCES}

1. Al-Jumaily WT, Al-Atar MA, Al-Tae AR, Mansour AD, Jiad JH, AbdulLatif $\mathrm{H}$. The incidence of salmonellae and serological evidence of Newcastle disease in some wild birds from Baghdad area. J Biol Sci Res 1989; 20: 213-9.

2. Soulsby EJL. Helminths, Arthropods and Protozoa of Domesticated Animals. 7 th ed. London: Baillière Tindall 1986.

3. Ritchie BW, Harrison GJ, Harrison LR. Avian Medicine: Principles and Applications. Lake Worth, FL: Wingers Publishing Inc1994.

4. Kaufmann J. Parasitic Infections of Domestic Animals: A Diagnostic Manual. Berlin: Birkhauser Verlag1996.[CrossRef]

5. Barnek BW, Barnes HJ, Beard CW, McDougald LR, Saif YM. Diseases of Poultry. 10 th ed. Ames, IA: lowa State University Press 1997.

6. Boado E, Zaldivar L, Gonzalez A. Diagnosis, report and incidence of diseases of the pigeon (Columba livia) in Cuba. Rev Cubane Cien Avicola 1992; 19: 74-8

7. Catelli E, Poglayen G, Terregino C, Orlando C, Tonelli A, IssaGadale O, et al. Survey of endoparasites of the digestive tract of Columba livia (Gmelin, 1789) in Florence. Selez Vet 1999; 2: 75-85.

8. Dranzoa C, Ocaido M, Katete P. The ecto-, gastro-intestinal and haemo-parasites of live pigeons (Columba livia) in Kampala, Uganda. Avian Pathol 1999; 28: 119-24.[CrossRef]

9. Toro H, Saucedo C, Borie C, Gough RE, Alcaino H. Health status of free-living pigeons in the City of Santiago. Avian Pathol 1999; 28: 619-23.[CrossRef]

10. Abdul-Karim RM, Jassim BA, Naser NS. Infestation and occurrence of ectoparasites (lice, ticks and mites) of pigeons in Erbil area. Bull Entomol, New Delhi 1988; 29: 173-7.

11. Wilson GWC. Newcastle disease and paramyxovirus 1 of pigeons in the European Community. World Poultry Sci J 1986; 42: 143-53.[CrossRef]

12. Abul-Hab J. Biting lice of chicken and pigeons in Baghdad area. Bull Biol Res Cent 1975; 4: 1-36.

13. Abul-Hab J. A list of Arthropoda of medical and veterinary importance recorded from Iraq. Bull Biol Res Cent 1980; 12: 9-39.

14. Al-Barwari SE, Nassir JK. First record of ten species of helminthic parasites from vertebrates in Iraq. Iraqi J Sci 1983; 24: 101-8.

15. Al-Janabi BM, Al-Sadi HI, Hayatee ZG. Some parasites of pigeons from Mosul province. J Coll Vet Med 1980; 1: 15-26.

16. Daoud MS, Al-Ani AJ. Pseudolynchia canariensis (Hippoboscidae: Diptera) from pigeon in Mosul, Iraq. Iraqi J Vet Sci 1989; 11: 271-2.

17. Eichler W. Fundamentals of Veterinary Entomology. Jena, Germany: VEB Gustav Fischer Verlag 1980.

18. Khalaf KT. A collection of insects from Iraq. Iraq Nat Hist Mus 1959; 17: 17-26.

19. Khalaf KT. Faunistic notes in Iraq. Bull Iraq Nat Hist Inst 1963; 2: 1-12.

20. Mustafa FAJ. Epidemic Study of Some Cestodes Infecting the Alimentary Canal of Pigeons. M. Sc. Thesis, Basrah University, Iraq1984.

21. Sawada I, Molan AL, Saeed IS. Further studies on avian cestodes in Iraq. Jpn J Parasitol 1990; 39: 36-41.

22. Shamsuddin $M$, Jasim MK. Coccidia of some birds and mammals from Iraq. Bull Nat Hist Res Cent 1980; 7: 81-110.

23. Shamsuddin M, Mohammad MK. Haematozoa of some Iraqi birds with description of two species, Haemoproteus pterocil and Leucocytozoa nycticoraxi (Protozoa: Haemosporina). Bull Nat Hist Res Cent 1980; 7: 111-55.

24. Zangana MF. Study on the Parasites of Domestic Pigeon Columba livia domestica in Nineveh and Some Areas of Erbil and Dohuk Provinces. M. Sc. Thesis, Mosul University, Iraq 1982.

25. Bennett GF, Peirce MA, Ashford RW. Avian haematozoa: Mortality and pathogenicity. J Nat Hist 1993; 27: 993-1001.[CrossRef]

26. Al-Barwari SE. Cell and Population Kinetics in the Irradiated Skin. Ph.D. Thesis, Faculty of Medicine, Manchester University, U.K. 1978.

27. Eichler W, Abul-Hab J. New and little known parasites of domestic animals. 5. Columbicola montschadskyi as a mallophagan parasite of domestic pigeons. Angew Parasitol 1974; 15: 184-200. 
28. Levine ND. Veterinary Protozoology. Ames, IA: lowa State University Press 1985.

29. Schmidt GD. Handbook of Tapeworm Identification. Boca Raton, FL: CRC Press Inc 1986.

30. Tsai SS, Yeh WS, Chi YG, Itakura C. Force-feeding and candidasis in pigeons. Avian Pathol 1994; 23: 569-74.[CrossRef]

31. Koroglu E, Simsek S. The prevalence of Eimeria species in pigeons (Columba livia) in Elazig. Firat Univ Saglik Bil Derg 2001; 15: 401-4.

32. Kulisic Z. Endoparasite fauna of pigeons (Columba livia) as detected in the City of Belgrade. Acta Vet Beograd 1988; 38: 37-42.

33. Martinez-Moreno FJ, Martinez-Mareno A, Becerra-Martell C, Martinez-Cruz M de S. Parasitic fauna of pigeons (Columba livia) in Cordoba Province, Spain. Rev Iber Parasitol 1989; 49: 279-81.

34. Toulah FH. A study of Trichomonas gallinae in pigeons (Columbia livia domestica) at Saudi Arabia (Jeddah area). J Egypt Gen Soc Zool 1997; 22: 1-14.

35. Tasca T, Carli GA, de Carli GA. Prevalence of Trichomonas gallinae from the upper digestive tract of the common pigeon, Columba livia in the Southern Brazilian State, Rio Grande do Sul. Parasitolog Dia 1999; 23: 42-3.

36. Earle RA, Little RM. Haematozoa of feral rock doves and rock pigeons in mixed flocks. S Afr J Wildl Res 1993; 23: 98-100.

37. Gulander A, Tuzer E, Cetinkaya H. Haemoproteus columbae infections and Pseudolynchia canariensis infestations in pigeons in Istanbul, Turkey. Istanbul Univ Vet Fak Derg Istanbul 2002; 28: 227-9.

38. Senlik B, Gulegen E, Akyol V. Prevalence and intensity of Haemoproteus columbae in domestic pigeons. Indian Vet J 2005; 82: 998-9.

39. Sol D, Jovani R, Torres J. Geographical variation in blood parasites in feral pigeons: The role of vectors. Ecography. Pattern Divers Ecol 2000; 23: 307-14.

40. Da Silva OC, De Mattos-Junior DG, Ramires PM, Cezar-da-Silva C, Garcia-de-Mattos-Junior D. Helminth parasites of Columba livia in Sao Goncalo, Rio de Janeiro. Arq Bras Med Vet Zootec 1990; 42: 391-4.

41. Al-Aloosi JAA. A Survey of Alimentary Canal Helminths of Two Birds; Gul (Larus ridibundus) and Wood Pigeon (Columba palumbus) From Baghdad and Baiji Areas. M. Sc. Thesis, Baghdad University, Iraq 1985.

42. Chahota R, Katoch RC, Jithendran KP, Asrani RK. Helminthic infestations among free-living fauna around Dhauladhar Valley of Himachal Pradesh. Indian J Anim Sci 1997; 67: 302-3.

43. Al-Hubity IA, Al-Habib WMS. A survey of the helminth parasites of the domestic fowl (Gallus gallus domesticus) in Mosul district, Iraq. Mesopotamia J Agric 1979; 14: 197-205.
44. Magzoub M, Kasim AA, Shawa Y. Three new species (Cestoda: Davaineidae) from the rock pigeon Columba livia domestica with comments on the infection. J Coll Sci, Riyadh Univ 1980; 11: 119-27.

45. Al-Barwari SE, Saeed I. Parasitoses of the chukar partridge, Alectoris chukar in north Iraq 2012. (submitted to Acta Parasitologica Turcica).

46. Srivastava RN, Srivastava VC. An ecological study of the prevalen$\mathrm{ce}$, mean intensity and relative density of the cestode infection in relation to the sex of the host in the pigeon Columba livia (Gmelin) in Allahabad. Flora and Fauna (Jhansi) 2000; 6: 85-8.

47. Wardle RA, McLeod JA. The Zoology of Tapeworms. Minneapolis: The University of Minnesota Press1952.

48. Al-Khalidi NW, Daoud MS, Al-Taee AF. Prevalence of internal parasites in chicken in Mosul, Iraq. Iraqi J Vet Sci, 1988; 1: 18-23.

49. Senlik B, Gulegen E, Akyol V. Effect of age, sex and season on the prevalence and intensity of helminth infections in domestic pigeons (Columba livia) from Bursa province, Turkey. Acta Vet Hung 2005; 53 : 449-56.[CrossRef]

50. Anderson RC. Nematode Parasites of Vertebrates: Their Development and Transmission. 2nd ed. Wallinford, Oxon, UK: CABI Publishing 2000

51. Hamad-Ameen KA, Al-Iraqi RA. Survey and identification of lice species on chicken in Erbil governorate. Iraqi J Vet Sci 2007; 21: 13-21.

52. Hassan MA, Taee AF, Daoud MS. Observations on some ectoparasites of ckicken in Mosul (Iraq). J Vet Parasitol 1989; 3: 67-8.

53. Al-Ani AJ, Daoud MS, Al-Bayati MMA. A study of ectoparasites in turkeys in Nineveh, Iraq. Iraqi J Vet Sci 1994; 7: 41-4.

54. Gulanber A, Tuzer E, Cetinkaya H. A survey on lice infestations of pigeons in Istanbul, Turkey. Istanbul Univ Vet Fak Derg 2002; 28: 231-4.

55. Tigin Y. Ectoparasites of domestic pigeons (Columba livia). Ankara Univ Vet Fak Derg 1973; 20: 372-90.

56. Adams RJ, Price RD, Clayton DH. Taxonomic revision of Old World members of the feather louse genus Columbicola (Phthiraptera: Ischnocera), including description of eight new species. J Nat Hist 2005; 39: 3545-618.[CrossRef]

57. Johnson KP, Reed DL, Parker SLH, Kim D, Clayton DH. Phylogenetic analysis of nuclear and mitochondrial genes supports species groups for Columbicola (Insecta: Phthiraptera). Mol Phylogenet Evol 2007; 45: 506-18.[CrossRef]

58. Al-Muffti SA, Tayeb IT. Survey of poultry tick Argas persicus (Argasidae) in Dohuk governorate. J Dohuk Univ 2004; 7: 13-6.

59. Hoogstraal $\mathrm{H}$. Argasid and nuttallielid ticks as parasites and vectors. Adv Parasitol 1985; 24: 136-220.[CrossRef] 